\title{
THE GAME "YOUNG SCIENTISTS “ AS ACTIVE SCIENCE EDUCATIONAL TOOL FOR EXTRA-CURRICULAR WORK IN THE SCHOOL
}

\author{
Yuri Orlik', Elizabeth Gil' ${ }^{1}$, Luz C. Hernández ${ }^{2}$ \\ The Group of Science Education, Faculty of Science, Pontifical Javeriana University, \\ Bogotá, Colombia \\ ${ }^{2}$ Journal of Science Education
}

\begin{abstract}
In this work the results of organizing the scientific game "Young scientists" are shown. This game was carried out in three secondary and high schools in Bogota with about two hundred students from $9^{\text {th }}$ grade. Different teams of students competed with each other answering questions and doing special tasks in this game. This activity, outside normal classes, showed positive results in increasing level of students' interests to study science subjects and provided space for raising motivation, stimulating learning and developing high levels of skill in students.
\end{abstract}

Key words: scientific game, young scientists, motivation, extra-class activities.

\section{Introduction}

Engaging students in enjoyably scientific activity beyond the normal curriculum is one important way to improve the quality of knowledge and skills and provide better motivation of students. There are different variants of science extra-curricular work for physics, chemistry, biology, mathematics and other science subjects: schools and national Olympiads, organizing science clubs and circles of interests in different topics of science subjects, research projects, outside visits and others (Baikova, 1984; Roberts, 2000; Orlik, 2002.)

Scientific games represent interesting possibilities for science teachers in this way. These games can be organized in different modes such as: science theatre, games-exercises, science adventures, computer games in science (Navas, Orlik, 2003). These extra-curricular activities can increase the interest and motivation of teachers in learning science - as well as those of their students.

One opportunity for using games in secondary school and university extra-curricular work is the application of games between different groups of students as a science competition. This variant allows the science teacher to develop in students important knowledge, skills of discussion, collaborative work, increase the desire to know more about science by reading popular science books, consulting Web and so on. This interesting mode of extra-curricular activities has been applied in the different countries, for example, in former Soviet Union and Russia as special creative games $(\mathrm{KVN})$ for the secondary school and university level students (the actual examples of this game exist in USA and EU too, for example, see http://www.kabh.org/english.htm, http://www.ligakvn.de/) The aim of this paper is to show the positive opportunities of organization of the scientific game "Young scientists " for students in secondary and high schools.

\section{Methodology}

The game "Young scientists" was organized in the three District secondary schools in Bogotá in the $1^{\text {st }}$ semester 2004. The Group of Science education (GSE) of the Pontifical Javeriana University (PUJ) has organised the game with these schools: Camilo Torres, Costa Rica, Palermo schools. IBM Colombia was the sponsor of this game and provided t-shirts as the prizes as well as CD disks with the introduction to the IBM educational site (www.tryscience.org). 
The plan of this activity was:

Organizing the preliminary part of the game in 3 secondary schools and the final between 3 secondary school teams held at the University. To prepare the game the staff of the GSE organized various meetings in advance of the game with secondary and high school teachers of science to explain the methodology of this activity. Then, with the participation of secondary school teachers and staff of the GSE, special scripts were designed for the preliminary part. These scripts included:

- the science with 12-15 questions about science (mathematics, physics, chemistry, biology, astronomy). The level of these questions corresponds to the curriculum of these subjects for $9^{\text {th }}$ grade. The questions contained original material that stimulated thinking, reasoning, creative reflection, problem solving and other high level cognitive skills of students. 4-5 special questions for the 'public' (the students who were not taken part directly in the game) were prepared too.

- the cultural part of the programme includes 4-5 special activities for students with dances, music and songs.

The preliminary rounds of the game were organized in each secondary school as a scientific and cultural extra-curricular activity and the school administration arranged a special big room for that.

From three to five teams of the $9^{\text {th }}$ grade students participated in the game in each school. Each team included 10-15 students. A jury of 4-5 teachers provided the score for each question for the team that answered correctly and was responsible for managing this activity. Each question was showed on a screen and then all team had a short time (1 minute or more in the case of more difficult questions) to answer it in writing and to send the answer to the jury for qualification (1 picture). At the end of the game the team, that got most points, won the game. The students from the winning team obtained special prizes as the books, t- shirts, CDs etc. The representative of 'public' who did not take part directly, got prizes too when they answered their questions correctly. All student and teachers who took part in these activities were presented with a certificate from the school administration and the GSE.

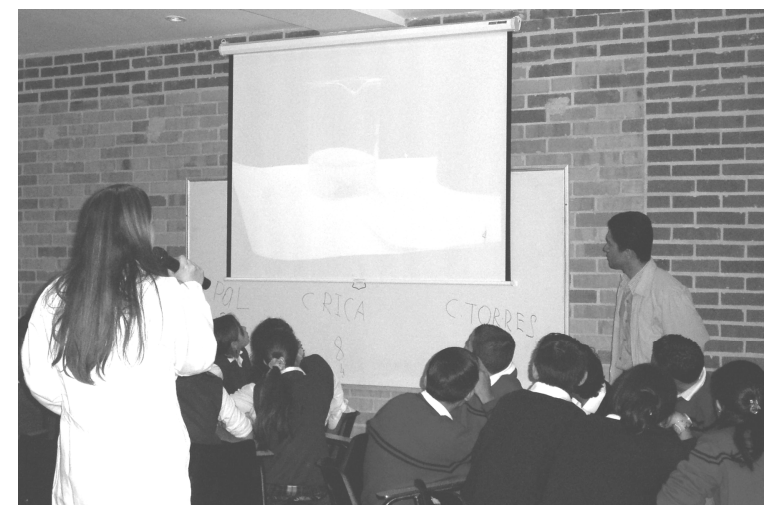

Picture 1. Each question was showed on a screen

Winning teams from the three secondary schools (10 -15 students in each team) took part in the final stage of the game in the Faculty of Science of the Javeriana University. In this case the GSE designed the special script, the structure of this was similar a those for preliminary parts. Some questions from the final script are in Table 1. The final game was developed in a similar way to encourage active participation of students. Teachers from schools were present too with $10-20$

students who did not take part directly in the game. The special jury included members of the GSE. The group of Palermo secondary school won the game and gained the special prize - the computer that was provided by the Faculty of Science of the Javeriana University.

Table 1

Examples of some questions from scripts

$\circ$ Explain the cause of the grey or black colour of many different cathedrals from the big 
cities built in marble (provide detailed explanation, if possible).

- How can you distinguish uncooked and boiled eggs by simple mechanics experiments

- (provide detailed explanation of this experiment, if possible).

- Why is sea water salty?

How can you obtain cheese from milk? (provide detailed explanation, if possible).

Students only used their own and group knowledge without consulting of additional sources of information when they answered questions in the preliminary and final stages of this game.

\section{Results and discussion}

About two hundred $9^{\text {th }}$ grade students from three Bogota secondary schools took part in both stage (preliminary and final) of the scientific game "Young scientists ". The difficulty of tasks and questions designed for that was of the intermediate level relevant to the contents of the corresponding curriculum and textbooks. Games were organized to provide opportunities for science competition between students of corresponding teams and for student who did not take part directly (the public). This aspect was positive and helped develop new social relations between students.

The observations of members of the GSE, teachers and participants allow us to say that this activity creates space for increasing the interests of students in studying science. The form of this game is the game-competition and this aspect also stimulated active participation by students. It is important that this activity was not the individual competition (that is often the case, for example, in Olympiads). The participation of each student in team discussions when searching for the correct answer during the time provided stimulated their capacities and developed some important high level skills. It was important too that during the game all participants could review their knowledge about mathematics, chemistry, physics, biology and other science subjects. Each student could also review their own capacity to find the correct answer in the limited time available.

The game was very useful for teachers too. First of all they took part actively in all parts writing and editing script materials and organizing the game in the respective secondary schools. The scientific and methodological quality of the script is very important in the first stage, because all questions should be well designed and have an appropriate level of difficulty. Questions and tasks must be creative, provide incentive and should be linked with the real life. The boring variant and questions of poor quality must be avoided. In scripts both open and multiple-choice questions were used. A lot of effort by teachers with their students was spent providing a suitable environment for the game, preparing rooms, computers and audiovisuals, decorating rooms, preparing special written science slogans and so on.

For many teachers too this game provided a lot of material and new experience to reanalyze their own class work and improve different parts of their educational process. All teachers who took part in this game expressed their desire to continue such and another similar extra-curricular activities for science education.

At the end of the game in each secondary school a questionnaire was given to the participants to find the level of their satisfaction and opinions about this extra-curricular activity. Answers showed a high level of satisfaction with this game (95\%) and desire to repeat this activity. Giving reasons for these positive opinions students noted the dynamic and amusing space of the game, opportunities for better science learning, informal organization and a change from the usual monotony of classes. In general they preferred active methods of learning.

\section{Conclusions}

The organization of scientific game "Young scientists" in secondary and high schools showed an increase in the level of students' engagement and interest to study science subjects. 
This extra-curricular activity allowed provision of space for increasing motivation, stimulated students' capacities and developed high level skills. This activity can be recommended to teachers for increasing the level of educational process in science.

\section{Acknowledgements}

The authors thank the Dean of the Faculty of Science of the PUJ Dra. Ángela Umaña for her support and providing the computer as the main prize, the IBM Colombia office for providing prizes, teachers of secondary schools and the stuff of the GSE of the PUJ for the support in this activities.

\section{References}

Baikova V. (1984). Chemistry theatre. Petrosavodsk, Karelia, /in Russian/.

Navas A., Orlik Y. (2003). Educational computer games on science teaching. Journal of Science Education, No. 2., vol 4, pp. 92-95.

Orlik Y. (2002). Chemistry: active methods of teaching and learning. Iberoamerica Publ., Mexico, /in Spanish/.

Roberts K. (2000). Tundra - accessing science through theatre. Education in Chemistry, v. 37, n. 2, p. 33.

\section{Santrauka \\ ŽAIDIMAS „JAUNIEJI MOKSLININKAI“ KAIP AKTYVAUS GAMTOS MOKSLU巳 MOKYMO(SI) PRIEMONĖ NEFORMALIAM UGDYMUI MOKYKLOJE}

\section{Yuri Orlik, Elizabeth Gil, Luz C. Hernández}

Straipsnyje siekiama supažindinti su didaktinio žaidimo „Jaunieji mokslininkai“ organizavimo neformaliame gamtamokslinio ugdymo procese bendrojo lavinimo mokykloje metodika. Žaidimas organizuotas reminatis nepamokinių renginių organizavimo patirtimi (olimpiadų, konkursų, LIK ir pan.) keletoje Kolumbijos miestų. Minètuose renginiuose rungėsi 9 klasių mokiniai, atsakydami ị iš anksto parengtus klausimus bei atlikdami kitas užduotis. Žaidimo rezultatai parodè, kad palankiai vertina aktyvaus mokymosi metodus tiek formaliame, tiek ir neformaliame ugdymo procese. Pastebèta, kad žaidimas padidino mokinių susidomėjimą gamtos mokslų mokomaisiais dalykais (fízika, chemija, matematika ir kt.). Mokytojams šio žaidimo organizavimas sudarė sąlygas išanalizuoti pamokų medžiagą, savo metodinę patirti, paskatino aktyvaus mokymosi metodus pritaikyti formalaus gamtamokslinio ugdymo procese.

Raktiniai žodžiai: didaktinis žaidimas, gamtamokslinis ugdymas, neformalus ugdymas, gamtamoksliniai mokomieji dalykai, aktyvaus mokymosi metodai

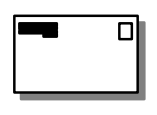

\section{Yuri Orlik}

The Group of Science Education, Faculty of Science, Pontifical Javeriana University, Bogotá, Colombia

E-mail: oen85@yahoo.com

\section{Elizabeth Gil}

The Group of Science Education, Faculty of Science, Pontifical Javeriana University, Bogotá, Colombia

E-mail: oen85@yahoo.com

\section{Luz C. Hernández}

Journal of Science Education

Home page www.colciencias.gov.co/rec 